\title{
Tracheocutaneous fistula- A surgical challenge
}

\section{PRAMOD CHIRAKKAL ${ }^{1}$ and Amira Al Hail ${ }^{1}$}

\author{
${ }^{1}$ Hamad Medical Corporation
}

November 26, 2020

\begin{abstract}
We are experienced a challenge for the surgeon for tracheocutaneous fistula closure in managing such a complication such as chronic cough, infection and other co-morbidities. The need for a secondary closure is also warranted when the stoma does not close on itself within a specified time.
\end{abstract}

TRACHEO-CUTANEOUS FISTULA- A Surgical challenge

ABstract

Tracheostomy is a general surgical procedure performed by many surgeons on a routine basis. A tracheostomy orifice closes by secondary intention in man Keywords:

Tracheostomy, Pectoralis major musculocutaneous flap, fistula

Key Clinical Message:

Tracheocutaneous fistula presents a challenge to the surgeon as different factors affects its formation and healing. A multidisciplinary approach and proper patient counselling, duration of cannulation.comorbidies helps in prognosis and outcome.

\section{CASE REPORT}

The patient was a 54-year-old male who is diagnosed with squamous cell carcinoma of the right vocal cord for which he had undergone microlaryngeal sur DISCUSSION

A tracheocutaneous fistula is commonly regarded as a pathological complication of temporary tracheostomy that results due to failure of spontaneous trac In conclusion, TCF presents a challenge to the surgeon as different pathogenic factors affect its formation and healing. A multidisciplinary approach is ver Author Contribution

The author confirms sole responsibility for the following: study conception and design, data collection, analysis and interpretation of results, and manuscript preparation

\section{Conflict of interest:}

The authors whose names are listed above certify that they have NO affiliations with or involvement in any organization or entity with any financial interest and no conflict of interest in the subject matter or materials discussed in this manuscript.

Acknowledgement statement:

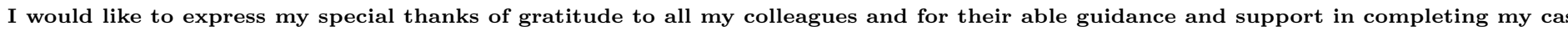




\section{REFERENCES}

Berbholz L, Vail S, Berlet A. Management of trachea cutaneous fistula. Arch Otolaryngol Head Neck Surg1992;118:869-71

- Eliashar R, Sichel JY, Eliachar I. A new surgical technique for primary closure of long-term tracheostomy . Otolaryngol Head Neck Surg 2005; 1

- Kulber H, Passy V. Trachea cutaneous closure and scar revision. Arch Otolaryngol 1972; 96:22-6

- Khaja SF, Fletcher AM, Hoffam HT. Local repair of persistent trachea cutaneous fistula. Ann Otol Rhinol Larnygol 2001; 120:622-6

- De Virgilio A, Fusconi M, Gallo A, et al. The oncological radicality of supracricoid partial larygectomy with cricohyiodopexy in the treatment of

- Bussu F, Paludetti G, Almadori G, et al.Comparison of total laryngectomy with surgical and non-surgical organ preservation modalities in adva

- De Vincentiis M, De Virgilio A, Bussu F, et al.Oncological results of the surgical salvage of recurrent Laryngeal SCCin a multicentric retrospect

figure 1 Non healing tracheostoma

figure 2- Pectoralis musculocutaneous flap and stoma closure

figure 3 - Pus discharge from donor site

\section{Hosted file}

TCF-figures 1-4

figure 2.pdf

available at https://authorea.com/users/378948/articles/495338-tracheocutaneous-fistula-asurgical-challenge 